\title{
Landslide Vulnerability and Risk Assessment: A Study at Kiriketioya and Belihuloya Watershed
}

Dananjaya P.K.V.S ${ }^{1}$ and Edirisooriya K.V.D ${ }^{2}$

\section{Abstract}

Sri Lanka is a continental island consisting of $65,610 \mathrm{~km}^{2}$ of land. The country is highly likely to affect by both natural and man-made hazards. Landslides can be identified as one of the major natural hazards. As a developing country, it is very important to identify landslide vulnerability and risks because that can influence future development activities and disaster mitigation programmes. Kiriketioya and Belihuloya watershed areas are located in the second and third pen plain of the country. It belongs to the Imbulpe Divisional Secretariat Division and approximately covers $72 \mathrm{~km}^{2}$ of land. The main objective of the study is to identify the landslide vulnerabilities and risks in the study area. The study was based on the data collected from both primary and secondary sources. Secondary data and information were collected through many sources as an extension to the literature review. Primary data were collected through field observations. Arc GIS 10.3 software was used for digitizing, modelling, data analysis and interpretation. Landsat $8 \mathrm{OLI} / \mathrm{TIRS}$ ( $30 \mathrm{~m}$ resolution) satellite images were used to calculate Normalized Different Vegetation Index (NDVI) and to analyze the land-usage. Weighted overlay methods in Arc GIS was used mainly to create landslide vulnerability map and the risk map. Landslide vulnerable and risk areas were identified and classified into high, medium and moderate zones. Areas of high risk of landslides are located in the high elevation areas. Approximately $60 \%$ of the lands of the study area have a moderate to high risk for landslides. Hence, it is essential to implement mitigatory measures to reduce landslide risks for the high and moderate landslides vulnerability lands.

Keywords: GIS, Imbulpe, Landslides, Risk, Vulnerability
${ }^{1,2}$ Department of Geography and Environmental Management, Sabaragamuwa University of Sri Lanka

${ }^{1}$ chandusridananjaya@gm ail.com 


\section{INTRODUCTION}

The term "landslide" describes a wide variety of processes that can result in the downward or outward movement of slopes forming materials, including rocks, soil, artificial fill or a combination of these materials the speed of the movement may range from very slow to rapid (Lynn et.al,2008). Moving of a large amount of materials can destroy property while harming people and livestock. Of the 65,000 sq.km of the land extent in Sri Lanka, nearly 20,000 sq.km encompassing 10 districts are prone to landslides. It is at about $30 \%$ of Sri Lanka's land area and spreaded into several districts, such as: Badulla, NuwaraEliya, Kegalle, Ratnapura, Kandy, Matale, Kaluthara, Mathara, Galle and Hambantota (Bandara, 2005). Landslide causes much damage to both human lives and built environments. In January 2007, over 450 families in the Hanguranketha and Walapane divisions were displaced due to a series of landslides (NBRO, 2009). From year 2000 to 2010 many lives were lost due to landslides, numerically 350 people and 9468 houses were damaged and destroyed due to landslides (Ministry of Disaster Management, 2014). The landslide occurred in May 2016 in the Kegalle district was tragic as it took the lives of 52 people and fully damaged 168 houses in the slope region (Vijekumara and Weerasinghe, 2016).

\section{RESEARCH PROBLEM}

During the past few years, the study area recorded many devastating landslides such as rock fall and slides that occurred in Puwakgahawela and Yakdehewala (Paraviyangala peak) areas. Six people were killed and two houses were completely destroyed from Puwakgahawela landslides and one person was killed by Paraviyangala landslides (NBRO, 2003, 2006). These landslides have been occurred due to natural causes while another landslide occurred on slopes modified by humans. Weathering processes, fluvial actions and slope patterns, geology, rainfall and land use pattern can be considered as causes of such landslides in the study area.

\section{Study Area}

The Kiriketioya and Belihuloya watersheds extend over $72 \mathrm{~km}^{2}$, is located in Imbulpe Divisional Secretariat consisting eleven Grama Niladari divisions (GNs) such as, Galagama, Seelogama, Belihuloya, Landuyaya, Muththettuwegama, Karagasthalawa, Kumbalgama, Kinchigune and Puwakgahawela villages (Figure 1). The total population in the study areas is 10488 . The study area belongs to the intermediate climatic zone with a mean annual rainfall of $1,400 \mathrm{~mm}$ to $2,000 \mathrm{~mm}$. The study area receives the highest rainfall during the North-East Monsoon period (December to February) that causes landslide risks of 


\section{Original Article}

the study area. The average recorded as at $28.3 \mathrm{C}^{\circ}$. temperature of the area has been

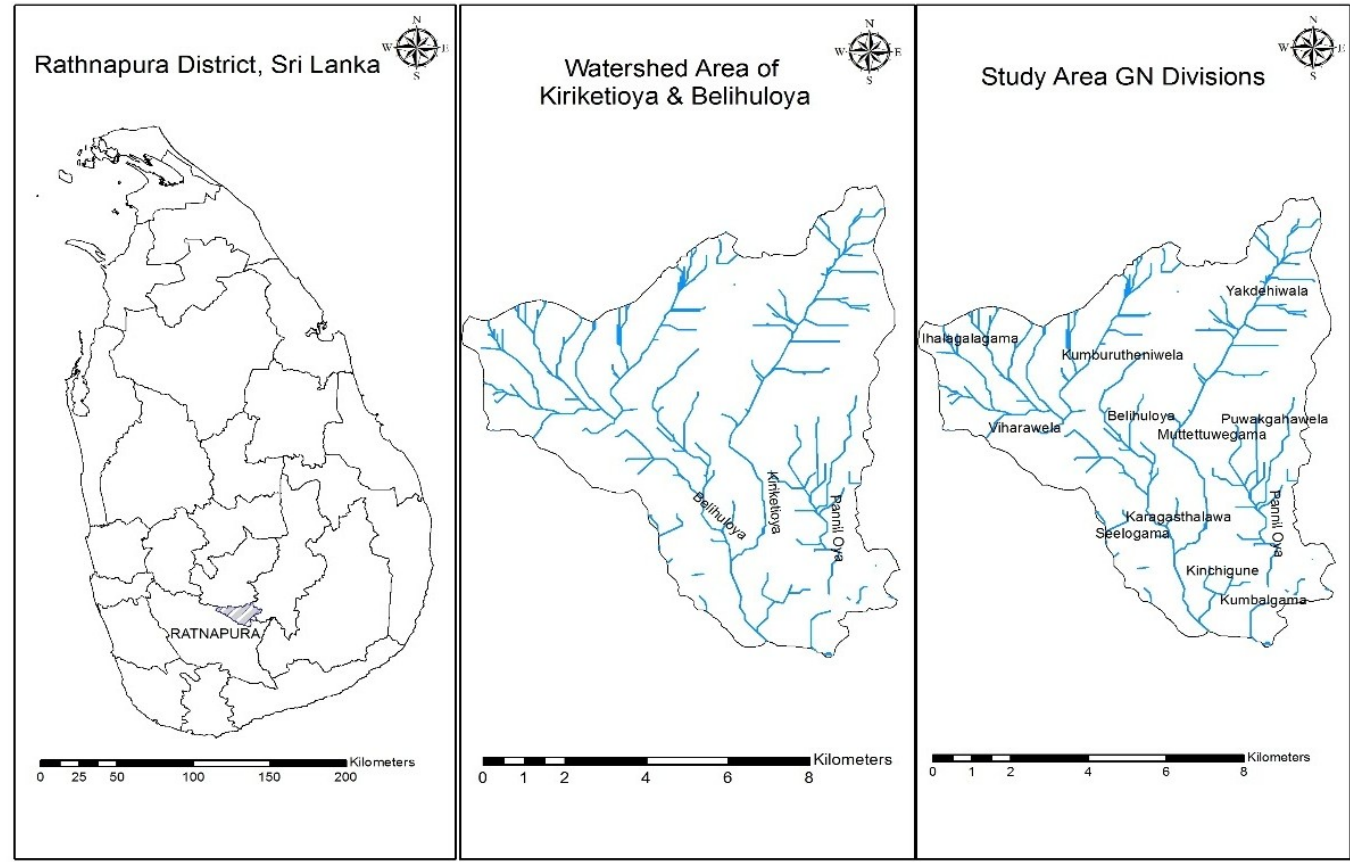

Figure 1 Geographical Location of the Kiriketioya and Belihuloya Watershed Area.

Source : Based on 1:50,000 (2007) Digital Data of Surveyor General's Department of Sri Lanka

\section{Objectives}

The main objective of this study is to identify landslide vulnerabilities and risks in the Kiriketioya and Belihuloya watershed; moreover a secondary objective is to examine the correlation between landslides and physical geographical conditions of the study area.

\section{LITERATURE REVIEW}

A significant increase in the attention directed by geo-scientists, engineering professionals, local communities and all levels of governments in Sri Lanka towards landslide hazards can be seen during the past few years. New technologies are being widely used for analyzing and identifying vulnerabilities for landslides. Jayathilaka and Munasinghe (2015) used quantitative method for identifying landslide risk and mapping in Sri Lanka. This study has been developed a human settlement map using the overlaying method, weighted method and pair wise ranking method. Mapping process was carried out using QGIS. The analyzed data included past satellite images and they helped identifying building density, open spaces and land usage. Weighted and pair wise methods have been developed in risk maps as high 


\section{Original Article}

risk, medium and low risk. This risk map can be employed to environmental investment as a guide plan for the development, early warning system and gathering further information on demographic and housing.

Virajh et.al (2012) studied susceptibilities to shallow landslide occurrences in the Kalawana Divisional division in Rathnapura District. This study employed two data collection methods such as fieldwork and laboratory test. An analytical hierarchical process was used to develop the attribute map.GIS data sets were combined by weighted average analysis (WAA), and landslide susceptibility map of the study area were created. The resulting information have compared with the landslide susceptibility map derived through the Slope stability analysis model (SINMAP). Both outputs are useful to better understand landslide susceptibility and were helpful for the reduction and mitigation of future landslide hazards of the study area. Edirisooriya et al. (2013) created a landslide zone map using a SINMAP model in the Elaphatha Divisional division of Rathnapura district. This model found $87 \%$ stable, $7 \%$ marginal and $5.62 \%$ having unstable land of the study area. Weerasingha et.al (2007) studied a deterministic slope stability predicting tool for the landslide vulnerability assessment in the Ratnapura Municipality. Slope stability analysis model (SINMAP) was used in this study. Furthermore, GIS technology was used to produce digital elevation model (DEM) and stability Index grid theme based on 1:10,000 scale contour data. The major output of the SINMAP model is the Stability Index grid theme that can be used as a landslide hazard zonation map. The model also provides slope area plot charts and statistical summary for each calibration region in the study area facilitating the data interpretation. The results of that study indicate about $72 \%$ reliability in predicting slope instability in the selected study area. The output of this result should be significant for the Geotechnical and geological evaluation of the site and implementing of the remedial measures and restricted practices of land usage to the unstable areas. However, it is important to increase the awareness of people who utilize the mountainous areas, in general, regarding the possible causes of slope instability and the importance of applying better land use practices and construction practices.

\section{METHODS AND MATERIALS}

Figure 2 demonstrates how Primary and secondary data were collected. 


\section{Original Article}

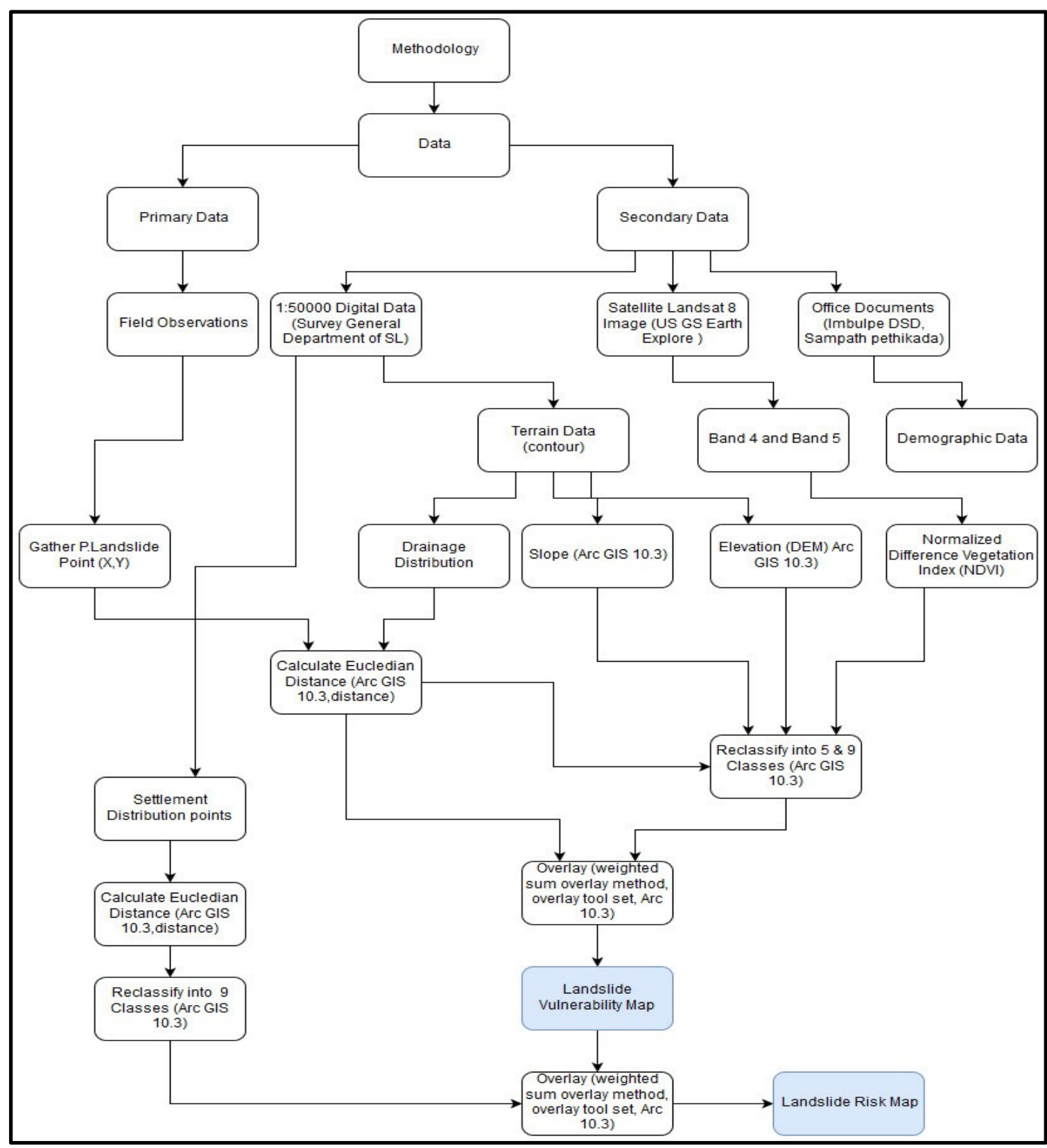

Figure 2: Methodology of Data collection in the Kiriketioya and Belihuloya Watershed. Source: Prepared by Authors

\section{Materials}

Secondary data and information were collected through different sources as an extension to the literature review. The secondary data sources such as Topographical maps, different thematic maps (digital and paper maps) at scales $1 ; 50,000$ (Kiriketioya and Belihuloya watershed area) were used for the preparation of digital elevation model (DEM), slope map, landslide hazard map and risk map. These topographic maps covered terrain layers, building layers, road network and which were produced under the DXB format by the Department of Survey of Sri Lanka. 


\section{Original Article}

Satellite images have been used provided free of charge by the USGS Earth Explore website to create a drainage distribution map of the study area. Other material related to the objectives of the study area obtained from reports and relevant literature.

Primary data were collected mainly through field observations and photographs. Field observation method was used for studying landslide vulnerable locations in the study area. The main purpose of taking photographs was to show visual information about the real hazard situation. . This source of information enabled the interpretation and analysis of the facts by comparing the photographs.

\section{Methods}

The steps followed (Figure 2) to reach the proposed goals are given below. Landslide vulnerability and risk map were made based on digital elevation model, slope map settlement and land use map of the study area using Arc GIS 10.3 software. Satellite images and NDVI techniques were employed to make land usage map of the study area. Normalized Differences Vegetation Index (NDVI) was used to identify vegetation density of the study area. To calculate NDVI the Lands at 8 OLI/TIRS (30m resolution) satellite images were used which were downloaded by the USGS Earth Explore web site (Table I).

Table I: Information of NDVI used Satellite Bands

\begin{tabular}{|c|c|c|c|c|c|c|c|c|}
\hline \multirow[t]{2}{*}{$\begin{array}{l}\text { Acquisition } \\
\text { Year }\end{array}$} & \multirow[t]{2}{*}{ Sensor } & \multirow[t]{2}{*}{ Path } & \multirow[t]{2}{*}{ Row } & \multicolumn{2}{|c|}{$\begin{array}{l}\text { Wave } \\
\text { Band }\end{array}$} & \multicolumn{2}{|c|}{ Spectral r. } & \multirow[t]{2}{*}{ Resolution } \\
\hline & & & & NIR & RED & NIR & RED & \\
\hline 2016-08-06 & $\begin{array}{l}\text { Landsat } \\
\text { OLI_TIRS }\end{array}$ & 141 & 55 & 5 & 4 & $\begin{array}{l}0.85- \\
0.88\end{array}$ & $\begin{array}{l}0.64- \\
0.67\end{array}$ & $30 \mathrm{~m} * 30 \mathrm{~m}$ \\
\hline
\end{tabular}

Source: - Image courtesy of the U.S. Geological Survey 2018

The following equation was used to calculate the Normalized Difference Vegetation Index.

$$
N D V I=\frac{N I R-R E D}{N I R+R E D}
$$

In the Landsat 8 images band 5 represents near infrared radiation (NIR) and band 4 represents visible radiation (RED). To calculate NDVI value, near infrared radiation (B5) minus visible radiation (B4) divide by near infrared radiation plus visible radiation ((B5-B)/

(B5+B4)). Calculation of NDVI given result which in between -1 to +1 when the value is near to -1 it means less 


\section{Original Article}

vegetation. When the value is near to +1 or in between $0.8-0.9$ it indicates the highest possible density of green leaves (NASA, 2000)

The calculated NDVI value was reclassified by using "Reclassify" tool in the spatial analysis tool set of Arc GIS 10.3. Before reclassification of the part covered by Samanala Wewa reservoir was removed by using "Conditional" tools of spatial analysis tools set. Modified NDVI map reclassified into 9 classes and added new values for the NDVI values(Table II).9 represents minimum NDVI value(low density of vegetation) and 1 represents the maximum NDVI value (high density of vegetation).

Table II: Reclassified NDVI Values of the study Area

\begin{tabular}{ll}
\hline NDVI Values & Reclassified values \\
\hline $0.060-0.1374$ & 9 \\
$0.1374-0.200$ & 8 \\
$0.200-0.255$ & 7 \\
$0.255-0.307$ & 6 \\
$0.307-0.358$ & 5 \\
$0.358-0.402$ & 4 \\
$0.402-0.443$ & 3 \\
$0.443-0.487$ & 2 \\
$0.487-1$ & 1 \\
\hline
\end{tabular}

Source: Prepared by Authors

Previous landslide point data thus were used to create most accurate landslide vulnerability map. Google Earth programme and Mobile Topographer software were used to collect GPS coordinates of previous landslides. Collected GPS data were added to the excel sheet. Those longitudes and latitude values were added to Arc map by using "Add XY Data" tool. Point data were added to the work background as a layer by using the export tool. "Euclidean Distance" tool was used to calculate distance from points to the surrounding area. The calculated Euclidean distance map was reclassified into 9 classes by using "Reclassify" tool in the spatial analysis tools and new values were assigned according to the distance from the landslide points (Table III).

Table III: Calculated Euclidean Distance Values \& Added New Values of Previous Landslide Points.

\begin{tabular}{ll}
\hline $\begin{array}{l}\text { Euclidean } \\
\text { distance }(\mathrm{km})\end{array}$ & Reclassified Values \\
\hline $0-0.0079$ & 9 \\
$0.008-0.016$ & 8 \\
$0.017-0.024$ & 7 \\
$0.025-0.032$ & 6 \\
$0.033-0.04$ & 5 \\
$0.041-0.048$ & 4 \\
$0.049-0.055$ & 3 \\
$0.056-0.063$ & 2 \\
$0.064-0.071$ & 1 \\
\hline
\end{tabular}

Source: Prepared by Authors

The generated slope map and elevation map (Figure 4) were reclassified using the reclassify tool of the spatial analysis toolset. In that, the slope values and elevation values were reclassified into five new classes and new values were assigned (Table IV). 


\section{Original Article}

"Natural Breaks (Jenks) method in Arc GIS 10.3 was employed in the reclassification process.

Table IV: Calculated Slope and Elevation Values and their New Added Values

\begin{tabular}{lll}
\hline $\begin{array}{l}\text { Slope } \\
\text { (Degree) }\end{array}$ & $\begin{array}{l}\text { Reclassify } \\
\text { value }\end{array}$ & $\begin{array}{l}\text { Elevation } \\
\text { (MSL) }\end{array}$ \\
\hline $0-5.23$ & 1 & $450-736.67$ \\
$5.24-15.45$ & 2 & $736.67-1070$ \\
$15.46-25.40$ & 3 & $1070-1416.67$ \\
$25.41-40$ & 4 & 1416.67 \\
& & 1796.7 \\
$40.1-66.78$ & 5 & $1796.7-2150$ \\
\hline
\end{tabular}

Source: Prepared by Authors

All reclassified layers of slope, elevation, drainage distribution, vegetation density and previous landslide points (Figure $3 \& 4$ ) were overlaid by using "Weighted sum overlay tool" in the spatial analysis tool set to create landslide vulnerability map. Weight values for each layer were assigned according to their influence on the landslide (Table V).

Table V: Weighted Values of the Study Area

\begin{tabular}{|c|c|c|}
\hline Raster Name & Field & Weight \\
\hline $\begin{array}{l}\text { Reclassified Slope } \\
\text { Reclassified }\end{array}$ & Value & 4.5 \\
\hline $\begin{array}{l}\text { Vegetation Density } \\
\text { (NDVI) }\end{array}$ & Value & 2.5 \\
\hline $\begin{array}{l}\text { Reclassified } \\
\text { Drainage } \\
\text { Distribution }\end{array}$ & Value & 2 \\
\hline $\begin{array}{l}\text { Reclassified } \\
\text { Landslide Point }\end{array}$ & Value & 0.5 \\
\hline $\begin{array}{l}\text { Reclassified } \\
\text { Elevation }\end{array}$ & Value & 0.5 \\
\hline
\end{tabular}

Source: Prepared by Authors
The created landslide vulnerability map was overlaid with Euclidean distance map of settlement distribution by using weighted sum overlay tool to create landslide risk map. Equal weighted values as "1" were assigned to the each layer. The landslide risk and vulnerability of the area is calculated under four categories, they are low vulnerable/risk, moderate vulnerable/ risk, high vulnerable/ risk and extremely vulnerable/risk.

In the landslide vulnerability and risk analysis, the area was calculated in square kilometers. For example, when the resolution value of the cell is $30 \mathrm{~m}$ * $30 \mathrm{~m}$. To calculate the area cell value $\left(900 \mathrm{~m}^{2}\right)$, it was multiplied by the cell count of each value range. Then, multiplied the value and divide it by 10000 to convert it into "hectares", because 1 hectare is equal to $10000 \mathrm{~m}^{2}$. To convert hectares in to square kilometers the hectare value is multiplied by 0.01 ., because there is $0.01 \mathrm{~km}^{2}$ in a hectare. 


\section{Original Article}

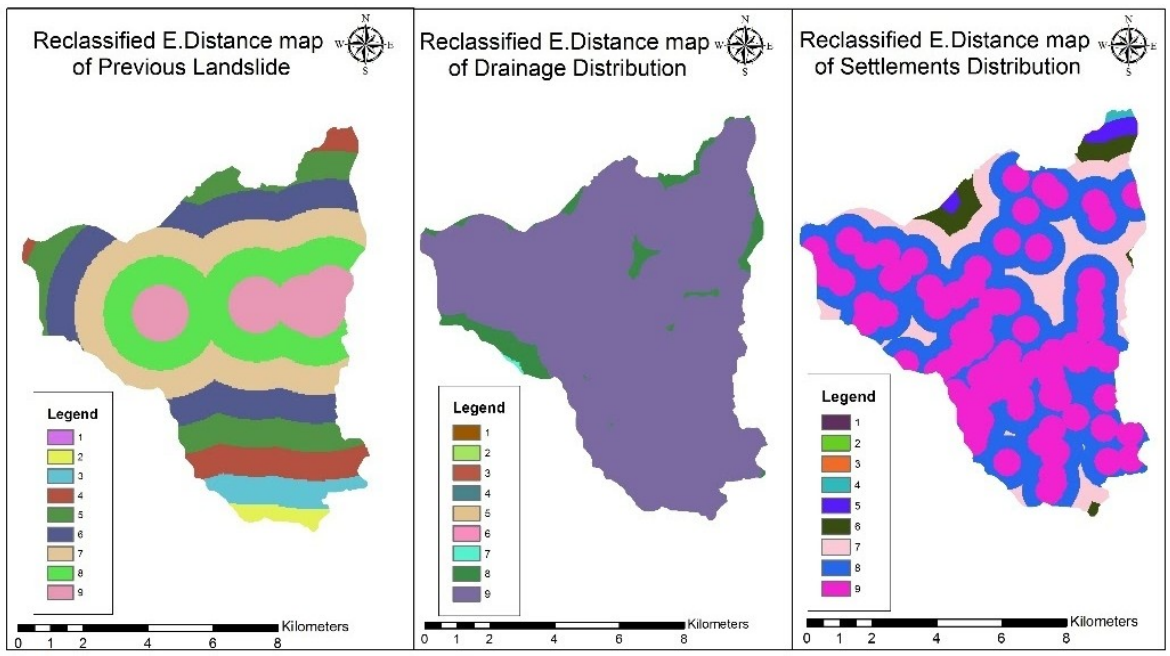

Figure 3 Reclassified Euclidean Distance Maps of Previous Landslide, Drainage Distribution \& Settlements Distributions

Source: Based on 1:50,000 (2007) Digital Data of Surveyor General's Department of Sri Lanka \& Field Data.

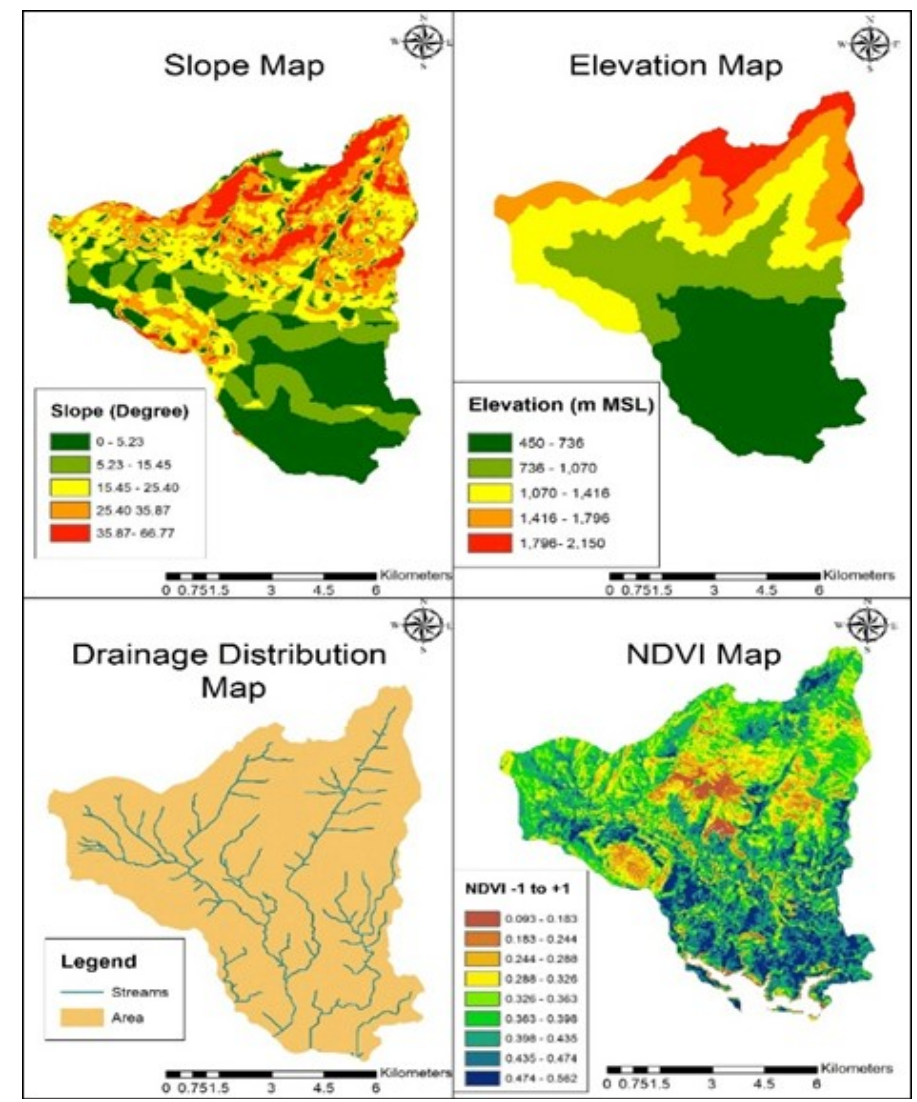

Figure 4: Slope, Elevation, Drainage Distribution and Calculated NDVI Maps

Source : Based on 1:50,000 (2007) Digital Data of Surveyor General's Department of Sri Lanka. 


\section{Original Article}

RESULTS AND DISCUSSION

The digital elevation model and NDVI classification was adopted in the mapping of landslide vulnerabilities of Kiriketioya and Belihuloya watershed.
Landslide vulnerable zones were categorized as low, moderate and high hazard zones (Figurer.5).

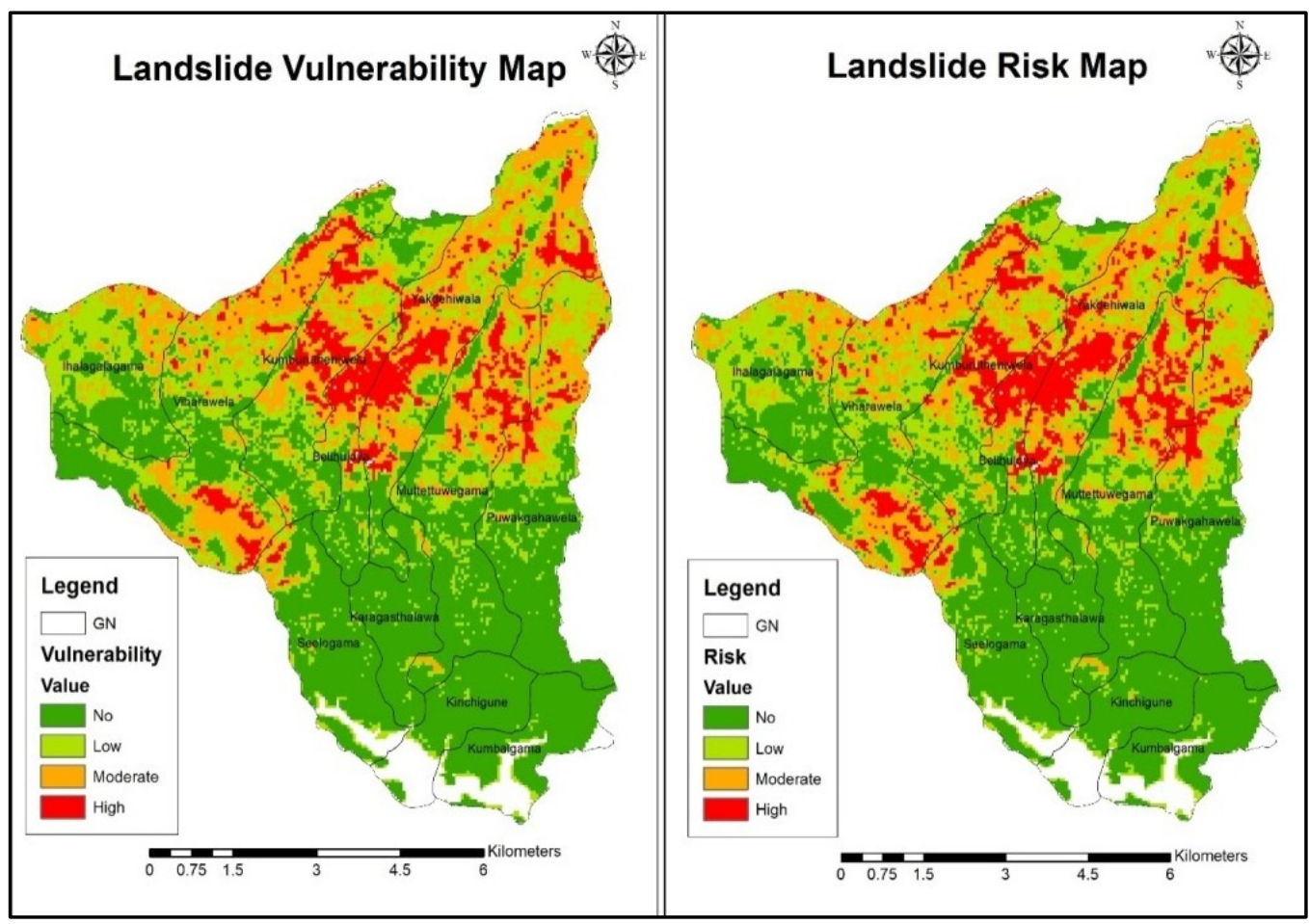

Figure 5: Vulnerability \& Risk Maps of Landslide Hazard

Source : Based on 1:50,000 (2007) Digital Data of Surveyor General's Department of Sri Lanka \& Analysis Results

Table VI shows $8.75 \%$ of the land area of the study area is extremely vulnerable to landslides. These include Nonperial, Nagaraka, Kumburutheniwela and Yakdehewala villages. These areas are approximately located in the high elevations $(800 \mathrm{~m})$ and consist of high slopes variations (65 - 90 degrees) and most of the slopes represent concave slopes. This area is covered with Red yellow and Colluviums derived from a wide variety of Precambrian metamorphic rocks from the upper parts of the risk area. These soil types are more likely to become saturated and can initiate movement during the rainy seasons of North Eastern Monsoon and Second Inter Monsoon (October- February). Geologically, the study area is an undifferentiated highland series with rock types such as Garnet - Sillimanite Quartz etc. During the field work, this lithology 


\section{Original Article}

was identified based on its characteristics using the hand specimen method. Tension crakes with direct affinity to the process of landslide vulnerability can be seen in the high risk areas of the study area. During the Monsoon periods, these crakes are exposed and subjected to the processes of chemical weathering which contributes to the rock falls and landslides.

Table VI: Landslide Vulnerability Zone of the Kiriketioya and Belihuloya Watershed

\begin{tabular}{ccc}
\hline $\begin{array}{c}\text { Land in } \\
\mathrm{km}^{2}\end{array}$ & Percentage & $\begin{array}{c}\text { Vulnerable } \\
\text { Zone }\end{array}$ \\
\hline 31.28 & $44.00 \%$ & Low \\
17.56 & $24.69 \%$ & Moderate \\
16.043 & $22.56 \%$ & High \\
6.22 & $8.74 \%$ & Extremely High \\
\hline
\end{tabular}

The moderate landslides vulnerability area has covered $24.69 \%$ land and namely Muththettuwegama, Ihalagalagama, and Kuburutheniwela GN divisions (Figurer 5).According to the field observation, these moderate risk areas can be identified with soil degradation problem, forest fires, and other improper land-use practices.

\section{CONCLUSIONS}

Overall, approximately $60 \%$ of the lands in the study area tend to be moderate and high risk. Therefore, it is recommended to implement mitigation activities to reduce landslide risk in the high and moderate landslides vulnerability lands. An Implementation of proper land use policies, maintain landslide inventory, replantation of bare mountain tops with native tree species to reduce land erosion, the establishment of community-based disaster mitigation societies and conducting awareness programmes on disaster mitigation are suggested.

\section{ACKNOWLEDGEMENT}

Authors would like to thank Divisional Secretary of Imbulpe Divisional Secretariat and all the Grama Niladharis (officers) who immensely contributed in field observations. Furthermore authors would like to thank Ms. C.M.U. Erandi Chandrasekara, Mr. Chamal Ishara Liyanarachchi and Mr. Anushan Lakshitha for their support in our research.

\section{References}

Bandara, R. M. (2005). Landslides in Sri Lanka. Vidurava, 22 (No: 02), 9-13.

Edirisooriya, K.V.D., Vithnage, N.S. \& Deheragoda, C.K.M,. (2013). Landslide Zoning Mapping of Vulnerability in Elaphatha Divisional Secretariat Division using Stability Index Mapping (SINMAP) Tool. International Journal of Humanities and Social Sciences, 3 (2), 137 144.

Jayathilake, D. \& Munasinghe, D. (2015). Quantitative Landslide Risk Assessment and Mapping. National building Reseach Organization symposium "Inovation For Resilient Environment. Sri Lanka. NBRO.

Lynn M.H. \& Peter B. (2008). The Landslide Handbook- A Guide to Understanding Landslides. Reston, Virginia: U.S. Geological Survey. 


\section{Original Article}

Ministry of Disaster Management. (2014). Sri Lanka comprehensive disaster management programme. 2014 - 2018, Sri Lanka. MDM.

NASA. (2000, August 30). Measuring Vegetation. Retrieved from Earthobservatory:

https://earthobservatory.nasa.gov/featur es/MeasuringVegetation/measuring_veg etation_2.php

National Building Research Organization (NBRO). (2003). Annual Report. Colombo: National Building Research Organization.

National Building Research Organization (NBRO). (2006). Annual Report. Colombo: National Building Research Organization.

National Building Research Organization (NBRO). (2009). Annual Report. Colombo: National Building Research Organization.

Vijekumara, P.A \& Weerasinghe, W.A.I.A. (2016). Permanent shelter options for Kegalle district landslide victims. NBRO International Symposium, (pp. 295-300).

Virajh, A. A \& Gunatilake, J. (2017). Assessing Shallow Landslide Susceptibility by Deterministic Model Approach 'SINMAP'. Journal of Geological Society of Sri Lanka, 18(2), 14-31.

Weerasingha , K.M , Abeywickrema, H.V.M.P., Fowze \& Samarakoon , J.S.M L. (2007). Use of Deterministic Slope Stability Prediction Tool for Landslide Vulnerability Assessment in Ratnapura Area, Sri Lanka. International Conference on Mitigation of Natural Disasters, (pp. 117). 